konferentsii-vyshcha-iurydychna-osvita-v-xxi-stolitti-vyklyky-j-perspektyvy rozvytku-04-hrudnia-2020-r/

6. Білічак О.А. Реформа юридичної освіти в Україні: проблеми і виклики. Освітня аналітика України. 2019. № 3(7). С. 57-68.

7. Про освіту: Закон України від 05.09.2017. URL: https://zakon.rada.gov.ua/laws/show/2145-19\#Text.

8. Про наукову і науково-технічну діяльність: Закон України від 26.11.2015. URL: https://zakon.rada.gov.ua/laws/show/848-19\#Text.

DOI https://doi.org/10.30525/978-9934-26-148-0-3

\title{
РЕФОРМУВАННЯ ЮРИДИЧНОЇ ОСВІТИ В УКРАЇНІ: ТЕОРЕТИКО-ПРАВОВИЙ АНАЛІЗ
}

\author{
Друга А. А. \\ аспірантка кафедри державно-правових дисииплін \\ Міжнародного гуманітарного університету \\ м. Одеса, Україна
}

Останнім часом здійснено низку кроків із змістовної модернізації системи освіти в Україні, котрі спрямовані на підвищення якості української освіти, з інтеграцією останньої в європейський науковоосвітній простір. Переорієнтація на європейські стандарти якості освіти дали потужний імпульс реформам, що мають на меті приведення діяльності вищих навчальних закладів до найкращих світових практик. Особливе місце в цьому процесі займає реформування юридичної освіти, адже як слушно зазначає С. Ківалов: «модернізація вищої юридичної освіти в Україні вимагає подолання низки проблем, серед яких найбільш актуальними $є$ : невідповідність структури підготовки спеціалістів реальним потребам суспільства, зниження якості освіти, відірваність від прикладних наукових досліджень в галузі права, повільні темпи інтеграції в європейський і світовий інтелектуальний простір» [2, с. 4].

Сучасним проблемам реформування юридичної освіти приділялась увага в працях багатьох вітчизняних науковців, зокрема, В. Андрейцева, О. Білічака, К. Воронової, О. Діденко, В. Кузнєцова, К. Павлюка, О. Петришина, В. Тація, О. Ткачука, О. Чумака та ін. Проте, аналіз джерельної бази та сучасних тенденцій реформування юридичної освіти в Україні вказує на недостатній науковий рівень розробленості даної тематики, що обумовлює актуальність даного дослідження. 
Мета дослідження - аналіз особливостей реформування юридичної освіти в Україні та визначення основних напрямів та проблем імплементації проекту Концепції реформування юридичної освіти.

За роки незалежності України пропонувались безліч концепцій та різного роду програм реформування юридичної освіти. Суттєвим кроком на шляху реформування юридичної освіти став проект Закону України «Про юридичну (правничу) освіту і загальний доступ до юридичної професії» [5]. Даний законопроект базується на проекті Концепції про реформування юридичної освіти [4].

Аналізуючи визначені проектом Концепції реформування юридичної освіти підходи до модернізації юридичної освіти можна зробити висновок, що вони зводяться до:

1) поділу юридичних професій на певні категорії;

2) посилення практичної складової юридичної освіти;

3) скорочення кількості вищих навчальних закладів, що займаються підготовкою юристів, за допомогою оновлення органів державного контролю, що будуть здійснювати контроль за якістю освіти;

4) запровадження єдиного спеціалізованого екзамену у формі тесту. Найбільш радикальним нововведенням проекту Концепції реформування юридичної освіти $є$ запровадження декількох категорій юридичної професії. До першої відносять так звані «регульовані види правничої діяльності» (суддя, прокурор, адвокат), з огляду на те, що основи їх діяльності визначені положеннями Конституції України та регламентуються спеціальними законодавчими актами. У другу групу автоматично потрапляють всі інші варіації правничого фаху, а саме, робота на посадах нотаріуса, юридичного радника, слідчого, керівників та спеціалістів юридичних служб державних органів, підприємств, установ та організацій тощо. Третю становить підготовка науковопедагогічних кадрів вищої категорії [4].

Із цього приводу О. Білічак зазначає, що «основною метою поділу юридичних професій на групи $є$ встановлення особливих вимог до підготовки фахівців, які по завершенню навчання в юридичних закладах вищої освіти практикуватимуть у сфері регульованих видів правничої діяльності, забезпечуючи більш ретельний відбір на навчання. Освітні послуги для осіб, які прагнуть оволодіти компетентностями, необхідними у подальшому для регулювання правничої діяльності, надаватимуться у правничих школах. До вступу у правничі школи допускатимуться особи, які засвоїли програму навчання за освітньопрофесійним ступенем «молодший бакалавр» і успішно склали іспити, що підтверджують достатній рівень знання ними іноземної мови, наявність аналітичного, критичного і логічного мислення. Навчання у 
правничій школі відбуватиметься за наскрізною освітньо-професійною програмою за спеціальністю «Право», без будь-яких спеціалізацій» [1, c. 60-61].

Таке нововведення нам видається досить спірним. По-перше, поділ юридичних кадрів на регульовані та нерегульовані види юридичної діяльності потребує визначеності від абітурієнта на момент вступу та унеможливлює подальшу зміну своєї професійної долі. Сьогодні ніщо не заважає науковцеві займатися юридичною практикою, обіймати посади судді, прокурора тощо i, навпаки, право останніх здобувати науковий ступінь. Видається досить сумнівним, що вимоги до професійного рівня фахівців, що включені до регульованих видів діяльності, є настільки відмінними, що це потребує їх підготовки не лише за окремими освітніми програмами, але й в окремих спеціалізованих навчальних закладах.

Ще однією новацією реформування юридичної освіти в Україні є посилення практичної складової юридичної освіти. Сучасний навчальний процес в вищих навчальних закладах, що готують правників перевантажений вивченням нормативно-правової бази, та недостатньо орієнтований на юридичну практику та поверхнево стимулює індивідуальну активність здобувачів вищої освіти. За твердженням В. Єлова, за нинішніх умов, коли йде кардинальне оновлення законодавства, а випускники юридичного ВН3 лише проходять курс навчання за традиційно-лекційною системою, яка спирається на правові дисципліни без набуття необхідних професійних навичок застосування норм матеріального права до реальних ситуацій, в які потрапляють їхні клієнти, вони відчувають себе не готовими повноцінно працювати як юристи, оскільки не вміють опитувати (брати інтерв’ю), консультувати клієнтів, складати та подавати юридичні документи, здійснювати підготовку до справи, брати участь у процесі, опитувати свідків, сторони, виступати у судових дебатах [цит. по 3, с. 5].

Попри важливість теоретичних знань в галузі юриспруденції, практична складова юридичної освіти відіграє визначальну роль. Сьогодні випускники юридичним факультетів, в значній мірі, не виправдовують очікувань роботодавців, і як наслідок, стикаються з проблемою працевлаштування. 3 іншого боку, результати кваліфікаційного оцінювання $з$ права, що проводяться до органів прокуратури, суду та адвокатури, засвідчують про низький теоретичний рівень підготовки, навіть працівників з багаторічним стажем. Це все, зайвий раз, доводить про необхідність скорішої модернізації юридичної освіти.

Після проголошення незалежності України відбулося значне зростання кількості людей, що мають юридичну освіти. Це стало 
можливим завдяки відкриттю багато чисельних юридичних факультетів в непрофільних вищих навчальних закладах та відкриттю комерційних вишів, де юридичний факультет став базовим. Юридична освіта за радянських часів була недосяжною вершиною для багатьох людей. На момент проголошення незалежності України юридичні факультети існували лише в чотирьох регіонах (у Києві, Одесі, Харкові та Львові) i при вступі потрібно було пройти серйозний відбір. Проте запропоновані ринкові відносини до надання освітніх послуг призвели до зростання в арифметичній прогресії кількості закладів, що готують правників i, як наслідок, до перенасиченості ринку праці працівників даної категорії. Комерціалізація юридичної освіти в нашій державі призвела до падіння ії якості.

3 метою вирішення даної проблеми в проекті Концепції реформування юридичної освіти було запропоновано низка заходів, спрямованих на скорочення кількості вишів, що надають юридичну освіту та підвищення якості останньої. Це має відбуватися завдяки тому, що далеко не всім вищим навчальним закладам, що готують правників вдасться підтвердити нові ліцензійні вимоги. Підвищення вимог до ліцензування освітньої діяльності юридичних вищих навчальних закладів можна вважати сильною стороною реформування юридичної освіти. Іншим чинником, що сприятиме скороченню вишів $є$ запровадження спеціальних тестових програм, що застосовуватимуться для оцінювання рівня знань вступників до юридичних вищих навчальних закладів та випускників бакалаврату і магістратури. Адже не секрет, що непрофільні та комерційні вищі навчальні заклади спрощують умови вступу та навчання, і як наслідок не гребують абітурієнтами з досить низьким освітнім рівнем та «схиляються» перед тими, хто справно платить копійку.

Ще одним кроком в реформуванні юридичної освіти в Україні $є$ запровадження єдиного спеціалізованого екзамену у формі тесту. 3 метою розроблення системи тестування для спеціальних вступних випробувань та складання Сдиного державного кваліфікаційного іспиту має бути створений Центр тестування при Міністерстві юстиції України [4]. Навчання за освітньо-професійною програмою «бакалавр» буде завершуватися складанням Єдиного державного кваліфікаційного іспиту та за його підсумками можна вступати до магістратури зі складанням Єдиного вступного іспиту з іноземної мови та Єдиного фахового вступного випробування. Після завершення навчання за освітньо-професійної програмою «магістр» також складається Єдиний державний кваліфікаційний іспит, за результатами якого випускникові 
присуджується кваліфікація «магістр» за спеціальністю «Право» або «Міжнародне право».

Підсумовуючи викладене, можна зазначити, що проект Концепції реформування юридичної освіти містить як позитивні, так і досить спірні положення, що потребують уважного вивчення з боку юридичної спільноти. Це досить тривалий процес, що потребує грунтовного аналізу зарубіжного досвіду підготовки юридичних кадрів, залучення науковців, які, безпосередньо, «творять» майбутніх фахівців-юристів, врахування правосвідомості, національної спадщини в зазначеній сфері та очікуваних результатів.

\title{
Література:
}

1. Білічак О.А. Реформа юридичної освіти в Україні: проблеми і виклики. Освітня аналітика Украӥни. 2019. № 3 (7). С. 57-68.

2. Ківалов С.В. Актуальні проблеми вищої юридичної освіти: зарубіжний досвід та перспективи в Україні. Актуальні проблеми політики. 2017. Вип. 60. С. 4-13.

3. Мудрак Р.М. Юридична клінічна освіта в системі правової освіти України. Юридичний науковий електронний журнал. 2020. № 9. С. 26-28.

4. Проект Концепції реформування юридичної освіти URL: https://mon.gov.ua/ua/news/mon-proponuye-dlyagromadskogo-obgovorennya-napracovanij-spilno-z-ministerstvom-yusticiyiukrayini-proekt-koncepciyi-reformuvannya

5. Проект Закону про юридичну (правничу) освіту і загальний доступ до правничої професіï. URL: http://w1.c1.rada.gov.ua/pls/zweb2/ webproc4_1?pf3511=62613

DOI https://doi.org/10.30525/978-9934-26-148-0-4

\section{ДО ПИТАННЯ СОЦІОКУЛЬТУРНОГО ДИСКУРСУ ТА ДОМАШНЬОГО НАСИЛЬСТВА}

\author{
Зінсу О. I. \\ аспірантка відділу докторантури та ад 'юнктури \\ Начіональної академії внутрішніх справ \\ м. Київ, Украӥна
}

В сучасних умовах глобалізаційних процесів, які характеризуються зближення правових систем світу та розвитком інформаційного 